\title{
Glucocorticoids: surprising new findings on their mechanisms of actions
}

\author{
Frank Buttgereit
}

Glucocorticoids are highly effective drugs that are used very widely to inhibit inflammation and to modulate the immune system. ${ }^{1-3}$ Their great importance in the treatment of various rheumatic diseases is undisputed. $^{4-7}$ However, although their introduction into clinical medicine was more than 70 years ago, we have understood only a fraction of their mechanisms of action. This is mainly due to their highly pleiotropic effects. ${ }^{8} 9$ A therapeutically used monoclonal antibody against tumour necrosis factor alpha (TNFalpha) neutralises this molecule, and that is it. In contrast, glucocorticoids as hormones regulate an estimated $20 \%$ of the entire genome. $^{1011}$ The synthesis of cytokines, chemokines, adhesion molecules, receptors and many enzymes, mediators and other proteins is either upregulated or downregulated. In addition, various mechanisms of their action exist whereby we distinguish between genomic and nongenomic effects. These underlying mechanisms of action are known in principle and discussed in detail elsewhere, ${ }^{312-14}$ so the current knowledge is only summarised here in the form of table 1 . However, our understanding of glucocorticoid-mediated immunoregulation still has substantial gaps, not only but especially regarding effects of glucocorticoids in specific cell types and their key cellular targets in particular disease states, and the actions these hormones broadly induce in cells and tissues versus those that are unique to the immune system. ${ }^{9} 15$

\section{GLUCOCORTICOID EFFECTS ARE HIGHLY DEPENDENT ON CELL TYPE}

Given this background, research in the field of glucocorticoids-sometimes justifiably referred to as 'old friends'1continues to be very active. If one enters the search term "glucocorticoids" in PubMed, you will get >230000hits. By comparison, the search term "TNF

Charité University Medicine, Department of Rheumatology and Clinical Immunology, Berlin, Germany

Correspondence to Professor Frank Buttgereit, Charité University Medicine, Department of

Rheumatology and Clinical Immunology, 10117 Berlin, Germany; frank.buttgereit@charite.de alpha inhibitors" gets only about 56000 hits. It may be objected that research on glucocorticoids has been going on much longer than that on TNFalpha inhibitors. However, even if you only look at the year 2018, for example, you will find 7900 hits versus 2300 hits. Therefore, it is not surprising that we keep learning unexpected news. For example, the Journal of Experimental Medicine published in 2019 an outstanding paper describing surprising and for rheumatologists and clinical immunologists relevant news in research into the effects of glucocorticoids. Franco et al have investigated the transcriptional effects of glucocorticoids at the level of signalling pathways for nine primary human cell types obtained from healthy donors. ${ }^{11}$ The cells studied included for example, B cells, CD4+ T cells, monocytes and neutrophils. The authors report that glucocorticoid effects are highly dependent on cell type with regard to the regulation of genes and signalling pathways. They found methylprednisolone to induce cell specific differences in the expression of more than 9000 unique genes or $\sim 17 \%$ of the human transcriptome. I agree with the authors' interpretation that these results lead to a fundamentally new mechanistic understanding of the effects of glucocorticoids. It is clearly not a onefits-all concept, but rather that these drugs trigger multifactorial, cell-specific effects. This finding has the potential to develop more selective, cell-specific immunoregulatory therapies.

\section{B-HYDROXYSTEROID DEHYDROGENASES REGULATE GLUCOCORTICOID EFFECTS}

Another example of unexpected significant new findings is published in Annals of Rheumatic Diseases. Fenton et al ${ }^{16}$ have dealt with a scientifically rather neglected area in glucocorticoid research, the prereceptor metabolism. As a background, the type 1 and type 2 (11ß-HSD 1 and $2)$, act as key regulators by changing the balance between active and inactive glucocorticoids. ${ }^{17}$ It is well known that in this way they have a major influence on the expression of glucocorticoid effects in the target cells. Endogenous (ie, physiologically produced) and exogenous (ie, therapeutically given) glucocorticoids circulate in both their active and inactive forms. The (mostly) hepatic $11 \beta$ HSD1 facilitates the systemic regeneration of biologically active glucocorticoids (cortisol/hydrocortisone, corticosterone, prednisolone) from their inactive forms (cortisone, 11-dehydrocorticosterone, prednisone) by its oxidoreductase $(11 \beta$ reductase) action. Through 11- $\beta$ dehydrogenation, this enzyme can also facilitate the reverse reaction to some small extent, but it is mainly the (renal) $11 \beta \mathrm{HSD} 2$, which unidirectionally inactivates glucocorticoids (figure 1A). ${ }^{1318}$

Fenton et al focused their research not on this systemic, but on the peripheral, intracellular glucocorticoid metabolism in target cells. Both active and inactive glucocorticoid molecules are lipophilic substances that can easily penetrate the cell membrane and thus enter the cytosol of targets such as primary and secondary immune cells, fibroblasts and osteoblasts. However, before they can bind to the cytosolic glucocorticoid receptor alpha to trigger genomic effects (table 1), also in the target cell the activation status is determined by intracellular metabolism via the $11 \beta \mathrm{HSD}$ enzymes. As in the liver, the nicotinamide adenine dinucleotide phosphate (NADPH)-dependent enzyme $11 \beta$ HSD1 causes local glucocorticoid activation by reduction. In contrast, the $11 \beta$ HSD 2 enzyme catalyses a rapid inactivation by oxidation through the reverse reaction. In order to investigate the contribution of the local 11 $\beta$-HSD1 enzyme to the local anti-inflammatory properties of glucocorticoids, the authors conducted carefully designed and performed experiments. The primary aim was to measure in murine polyarthritis models the anti-inflammatory properties of orally administered corticosterone in mice with global, myeloid and mesenchymal targeted transgenic deletion of $11 \beta$-HSD1. They show that the global deletion of $11 \beta$-HSD1 resulted in glucocorticoid treatment being ineffective, proven by findings of persistent synovitis, joint destruction and inflammatory leucocyte infiltration. This was partially reproduced with myeloid 11 $\beta$-HSD1 deletion (targeted towards neutrophils, macrophages and granulocytes), but not with mesenchymal 11ß-HSD1 deletion (targeting primary fibroblasts and osteoblasts). It was also found that paracrine GC signalling between cell populations can overcome targeted deletion of 11ß-HSD1. Taken all observations together, the authors conclude that 


\begin{tabular}{|c|c|c|c|}
\hline Category & \multicolumn{2}{|c|}{ Molecular mechanism } & Brief description \\
\hline \multirow[t]{9}{*}{ Genomic effects } & & & Mediated via direct or indirect interaction between the GC-GRa complex and DNA \\
\hline & Trans-activation & & Induction of gene expression \\
\hline & & Dimer transactivation & GC-bound GR $\alpha$ homodimers bind to DNA GREs to positively regulate downstream gene expression (induction) \\
\hline & & Monomer transactivation & $\begin{array}{l}\text { GC-bound GR } \alpha \text { monomers bind to GREs and recruit co-activators to influence secondary transcription factor } \\
\text { regulation, thereby positively regulating downstream gene expression }\end{array}$ \\
\hline & & Monomer tethering transactivation & $\begin{array}{l}\text { GC-bound GR } \alpha \text { monomers bind to a secondary transcription factor to positively regulate downstream gene } \\
\text { expression }\end{array}$ \\
\hline & Trans-repression & & Suppression of gene transcription \\
\hline & & Dimer transrepression & GC-bound GR $\alpha$ homodimers bind to DNA GREs to negatively regulate downstream gene expression (suppression) \\
\hline & & Monomer transrepression & $\begin{array}{l}\text { GC-bound GR } \alpha \text { monomers bind to GREs and recruit co-repressors to influence secondary transcription factor } \\
\text { regulation, thereby negatively regulating downstream gene expression }\end{array}$ \\
\hline & & Monomer tethering transrepression & $\begin{array}{l}\text { GC-bound GR } \alpha \text { monomers bind to a secondary transcription factor to negatively regulate downstream gene } \\
\text { expression }\end{array}$ \\
\hline \multirow[t]{5}{*}{ Non-genomic effects } & & & Do not require direct interaction of the GC-GRa complex with DNA \\
\hline & \multicolumn{2}{|c|}{ Non-specific physicochemical interactions with membranes } & $\begin{array}{l}\text { GCs at high concentration intercalate into membranes thereby changing their physicochemical properties as well as } \\
\text { activities of membrane-associated proteins }\end{array}$ \\
\hline & \multicolumn{2}{|c|}{ Chaperone protein signalling } & $\begin{array}{l}\text { Chaperone proteins released from the multi-protein complex after the binding of GCs to the GR } \alpha \text { modify signalling } \\
\text { pathways }\end{array}$ \\
\hline & \multicolumn{2}{|c|}{ Via cell membrane receptors } & $\begin{array}{l}\text { GCs bind to cell membrane-bound receptors and mediate transmembrane activity resulting in non-genomic } \\
\text { signalling }\end{array}$ \\
\hline & \multicolumn{2}{|c|}{ Competition for PI3K } & GC-bound GR $\alpha$ sequestrates PI3K, thereby interfering with downstream protein kinase B signalling \\
\hline
\end{tabular}

GC $\alpha$, glucocorticoid receptor alpha; GC(s), glucocorticoid(s); GREs, glucocorticoid response elements; PI3K, phosphoinositide 3-kinase.
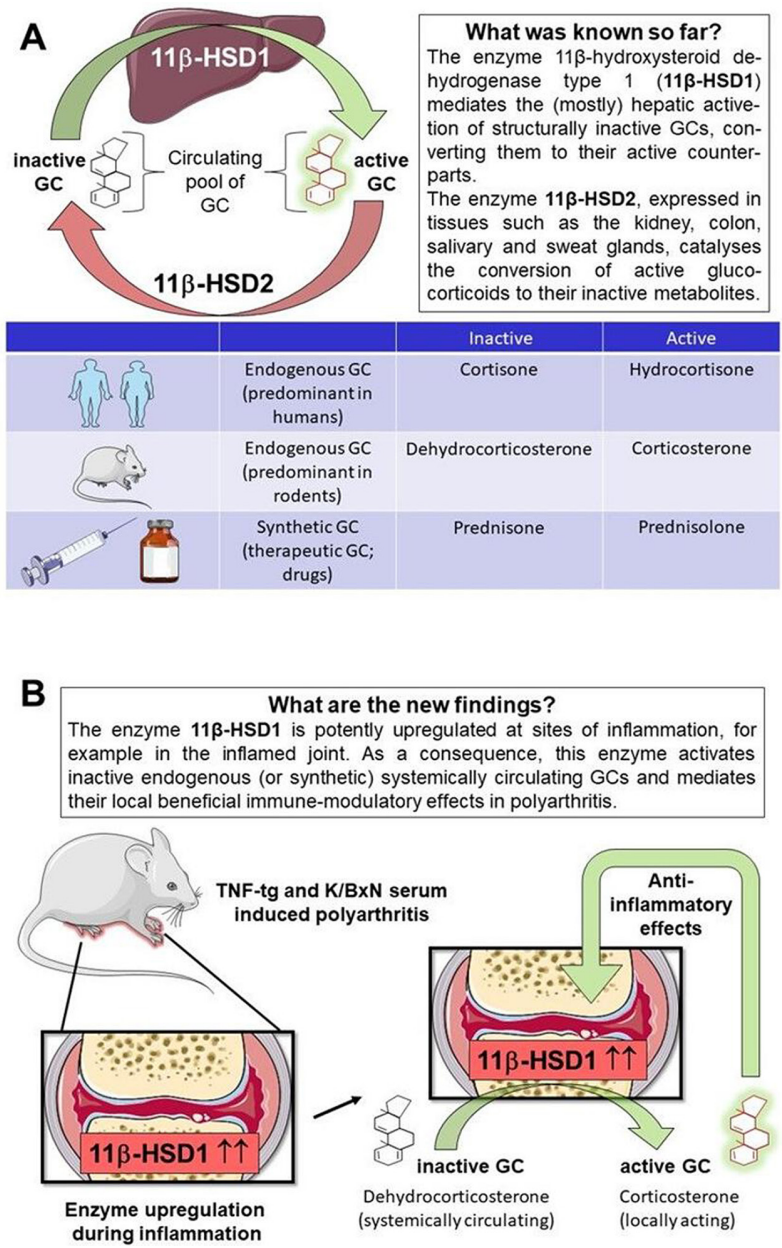

Figure 1 The functions of 11ß-HSD enzymes in the glucocorticoid (GC) metabolism. (A) GC circulate in both their active and inactive forms. The shuttling between these forms is mediated

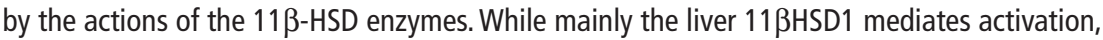
systemic inactivation is catalysed mainly by renal 11ßHSD2. (B) Fenton et al show additionally in murine arthritis models that the peripheral upregulation of $11 \beta-H S D 1$ in the inflamed joint leads to local reactivation of inactive GC molecules, which induces anti-inflammatory effects. glucocorticoid molecules, which have undergone systemic inactivation, are peripherally, that is, locally in the inflammation area, reactivated by the enzyme 11beta-HSD1 to induce profound antiinflammatory effects (figure 1B).

This study is certainly of great importance. It reveals a completely new, previously unknown component of the anti-inflammatory effect of glucocorticoids, namely and concisely, that systemically inactivated glucocorticoid molecules are peripherally reactivated by the enzyme 11beta-HSD1 to induce profound antiinflammatory effects. It should be critically noted, however, that this study has some limitations. First, it must be stressed that results obtained in animal models cannot always be replicated in humans. ${ }^{1920}$ Confirmation of the significance of the observations made for clinical medicine is therefore still pending. Second, it is not yet clear whether the identified mechanisms are also applicable to the local activation of therapeutically applied glucocorticoids such as prednisone, prednisolone or methylprednisolone. Third, a more comprehensive scientific picture should be created by including so far previously unconsidered leucocyte subpopulations such as $\mathrm{T}$ cells into considerations. Finally, the question remains whether the observations made can be translated into new therapeutic approaches.

It is to be hoped that a deepening of the knowledge gained with regard to glucocorticoid treatment and the proof of its relevance to clinical medicine will in future lead to a further improvement 
in the therapeutic options for treating patients with rheumatoid arthritis, and other rheumatic and inflammatory diseases, ultimately leading to a better benefit-risk ratio. ${ }^{21} 22$

\section{Handling editor Josef S Smolen}

Funding The author has not declared a specific grant for this research from any funding agency in the public, commercial or not-for-profit sectors.

Competing interests None declared.

Patient and public involvement Patients and/ or the public were not involved in the design, or conduct, or reporting, or dissemination plans of this research.

Patient consent for publication Not required.

Provenance and peer review Commissioned; externally peer reviewed.

(c) Author(s) (or their employer(s)) 2021. No commercial re-use. See rights and permissions. Published by BMJ.

\section{Check for updates}

To cite Buttgereit F. Ann Rheum Dis 2021:80:137-139.

Received 8 October 2020

Accepted 9 October 2020

Published Online First 8 November 2020

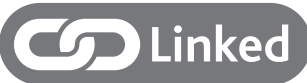

- http://dx.doi.org/10.1136/annrheumdis-2020218493

Ann Rheum Dis 2021:80:137-139.

doi:10.1136/annrheumdis-2020-218798
ORCID iD

Frank Buttgereit http://orcid.org/0000-0003-2534$550 X$

\section{REFERENCES}

1 Palmowski Y, Buttgereit T, Buttgereit F. The 70th anniversary of glucocorticoids in rheumatic diseases: the second youth of an old Friend. Rheumatology 2019;58:580-7.

2 Burmester GR, Buttgereit F, Bernasconi C, et al. Continuing versus tapering glucocorticoids after achievement of low disease activity or remission in rheumatoid arthritis (SEMIRA): a double-blind multicentre, randomised controlled trial. Lancet 2020;396:267-76

3 Strehl C, Ehlers L, Gaber T, et al. Glucocorticoids-AllRounders tackling the versatile players of the immune system. Front Immunol 2019:10:10.

4 Smolen JS, Landewé RBM, Bijlsma JWJ, et al. EULAR recommendations for the management of rheumatoid arthritis with synthetic and biological diseasemodifying antirheumatic drugs: 2019 update. Ann Rheum Dis 2020;79:685-99.

5 Hellmich B, Agueda A, Monti S, et al. 2018 update of the EULAR recommendations for the management of large vessel vasculitis. Ann Rheum Dis 2020:79:19-30.

6 Buttgereit F, Matteson EL, Dejaco C. Polymyalgia rheumatica and giant cell arteritis. JAMA 2020;324:993-4.

7 Palmowski Y, Buttgereit T, Dejaco C, et al. "Official View" on Glucocorticoids in Rheumatoid Arthritis: A Systematic Review of International Guidelines and Consensus Statements. Arthritis Care Res 2017;69:1134-41.

8 Rhen T, Cidlowski JA. Antiinflammatory action of glucocorticoids--new mechanisms for old drugs. N Engl $J$ Med 2005:353:1711-23.

9 Cain DW, Cidlowski JA. Immune regulation by glucocorticoids. Nat Rev Immunol 2017;17:233-47.

10 Galon J, Franchimont D, Hiroi N, et al. Gene profiling reveals unknown enhancing and suppressive actions of glucocorticoids on immune cells. Faseb $J$ 2002:16:61-71
11 Franco LM, Gadkari M, Howe KN, et al. Immune regulation by glucocorticoids can be linked to cell type-dependent transcriptional responses. J Exp Med 2019:216:384-406.

12 Syed AP, Greulich F, Ansari SA, et al. AntiInflammatory glucocorticoid action: genomic insights and emerging concepts. Curr Opin Pharmacol 2020;53:35-44.

13 Hardy RS, Raza K, Cooper MS. Therapeutic glucocorticoids: mechanisms of actions in rheumatic diseases. Nat Rev Rheumatol 2020;16:133-44.

14 Stahn C, Löwenberg M, Hommes DW, et al. Molecular mechanisms of glucocorticoid action and selective glucocorticoid receptor agonists. Mol Cell Endocrinol 2007;275:71-8.

15 Diaz-Jimenez D, Petrillo MG, Busada JT, et al. Glucocorticoids mobilize macrophages by transcriptionally up-regulating the exopeptidase DPP4. Biol Chem 2020;295:3213-27.

16 Fenton C, Martin C, Jones R. Local steroid activation is a critical mediator of the anti-inflammatory actions of therapeutic glucocorticoids. Ann Rheum Dis 2021;80:250-60.

17 Hardy R, Rabbitt EH, Filer A, et al. Local and systemic glucocorticoid metabolism in inflammatory arthritis. Ann Rheum Dis 2008;67:1204-10.

18 Buttgereit F, Zhou H, Seibel MJ. Arthritis and endogenous glucocorticoids: the emerging role of the 11 beta-HSD enzymes. Ann Rheum Dis 2008;67:1201-3.

19 Bracken MB. Why animal studies are often poor predictors of human reactions to exposure. $J R$ Soc Med 2009;102:120-2.

20 Weber M-C, Fischer L, Damerau A, et al. Macroscale mesenchymal condensation to study cytokine-driven cellular and matrix-related changes during cartilage degradation. Biofabrication 2020;12:045016

21 Buttgereit F, Bijlsma JWJ, Strehl C. Will we ever have better glucocorticoids? Clin Immunol 2018;186:64-6.

22 van der Goes MC, Strehl C, Buttgereit F, et al. Can adverse effects of glucocorticoid therapy be prevented and treated? Expert Opin Pharmacother 2016:17:2129-33. 